
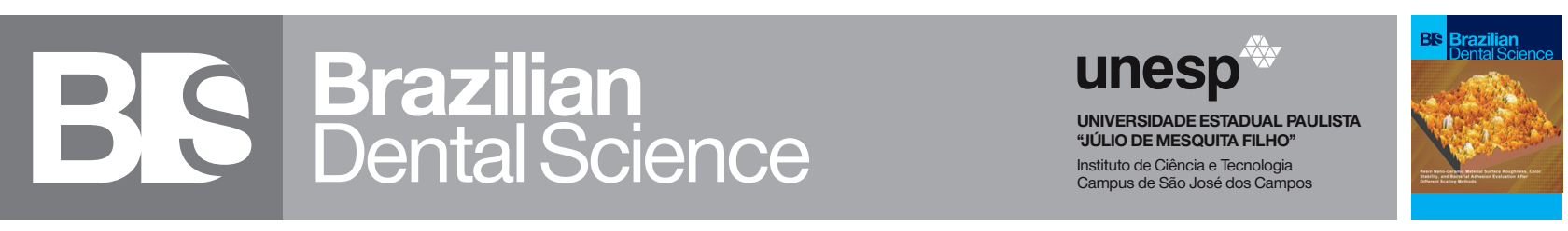

\title{
Enamel Deproteinization: Will It Save The Shear Bond Strength For The Sake Of Preventing White Spot Lesions?
}

\author{
Desproteinização do esmalte: salvará a resistência ao cisalhamento para prevenir lesões de manchas brancas? \\ Omnia A. ELHINY ${ }^{1}$, Dina A. EL-REFAI ${ }^{2}$ \\ 1 - Department of Orthodontics and Pediatric Dentistry, National Research Centre, Egypt. \\ 2 - Department of Biomaterials, Faculty of Dentistry, Ain-Shams University.
}

\section{ABSTRACT}

Objective: This study attempted to investigate the effect of enamel deproteinization using citric acid, PEG 400 and NaOCL on the shear bond strength of orthodontic brackets to enamel using nano-silver modified resin for the prevention of white spot lesions. Material and Methods: 68 premolars were used in the study; nano-silver modified adhesive resin was used to bond orthodontic brackets to the enamel. Specimens were divided into 4 groups according to the applied surface treatment before bonding. Group I (control): acid etching with 37\% phosphoric acid. Group II: deproteinization using $5.25 \%$ sodium hypochlorite $(\mathrm{NaOCl})$ before acid etching. Group III:deproteinization using $10 \%$ citric acid before acid etching. Group IV:deproteinization using 5\% polyethylene glycol (PEG 400) before acid etching. The specimens were then thermo- cycled for 6000 cycles. They were examined for surface roughness, shear bond strength and using electron microscope. Results: In both surface roughness and shear bond strength tests, Group III (citric acid) showed the highest values, followed by Group II (sodium hypochlorite); $(\mathrm{p}<0.001)$. The least values were shown for Groups I (control) and IV (PEG 400), with no statistically significant difference between them $(p=0.948)$. SEM revealed etching pattern type 1 and 2 in the citric acid group while PEG 400 showed shallower micro- porosities. Conclusions: Deproteinization of enamel using either $\mathrm{NaOCl}$ or citric acid increased the bond strength of nano-sliver modified resin to enamel, with citric acid showing greater increase in bond strength. Deproteinization using PEG 400 did not increase the bond strength.

\section{KEYWORDS}

Deproteinization; Sodium hypochlorite; Citric acid; PEG 400; Nano- silver modified adhesives.

\section{RESUMO}

Objetivo: Este estudo buscou investigar o efeito da desproteinização do esmalte utilizando ácido cítrico, PEG 400 e $\mathrm{NaOCl}$ na resistência ao cisalhamento de braquetes ortodônticos ao esmalte usando resina modificada com nanoprata para a prevenção de lesões de manchas brancas. Material e Métodos: 68 pré-molares foram usados no estudo; resina adesiva modificada com nanoprata foi usada para colar os braquetes ortodônticos ao esmalte. Os corposde-prova foram divididos em 4 grupos de acordo com o tratamento de superfície aplicado antes da colagem. Grupo I (controle): condicionamento ácido com ácido fosfórico a $37 \%$. Grupo II: desproteinização com hipoclorito de sódio a 5,25\% (NaOCl) antes do condicionamento ácido. Grupo III: desproteinização com ácido cítrico a $10 \%$ antes do condicionamento ácido. Grupo IV: desproteinização com polietilenoglicol 5\% (PEG 400) antes do condicionamento ácido. As amostras foram então termocicladas por 6.000 ciclos. Eles foram examinados quanto à rugosidade da superfície, resistência ao cisalhamento e usando microscópio eletrônico. Resultados: Nos testes de rugosidade superficial e resistência ao cisalhamento, o Grupo III (ácido cítrico) apresentou os maiores valores, seguido do Grupo II (hipoclorito de sódio); ( $\mathrm{p}<0,001)$. Os menores valores foram apresentados para os Grupos I (controle) e IV (PEG 400), sem diferença estatisticamente significativa entre eles $(\mathrm{p}=0,948)$. A microscopia eletrônica revelou padrão de ataque tipo 1 e 2 no grupo de ácido cítrico, enquanto PEG 400 mostrou microporosidades mais rasas. Conclusões: A desproteinização do esmalte com $\mathrm{NaOCl}$ ou ácido cítrico aumentou a força de união da resina modificada com nanoprata ao esmalte, com o ácido cítrico apresentando maior aumento na força de união. A desproteinização usando PEG 400 não aumentou a resistência de união.

\section{PALAVRAS-CHAVE}

Desproteinização; Hipoclorito de sódio; Ácido Cítrico; PEG 400; Adesivos modificados com nanoprata. 


\section{INTRODUCTION}

W hite spot lesions encountered during orthodontic treatment are considered a major clinical problem, not only for compromising esthetics; but also because they present the initial stage of caries [1]. Fixed orthodontic appliances complicate oral hygiene maintenance and increase the risk of developing white spot lesions [2,3-5].

Several mechanisms have been previously suggested to control the formation of white spot lesions which include the administration of topical agents containing fluoride or casein phosphopeptide-amorphous calcium phosphate (CPPACP). However, they had considerable limitations in noncompliant patients [6]. On the other hand, sealant application around the orthodontic brackets to form a physical barrier showed contradicting results, [7-9] while incorporating fluoride or chlorhexidine in the adhesive provide only short-lived results, [2] and a higher bond failure rate[1].

Silver-nano particles were found to have a potent antimicrobial effect, without causing enamel pigmentation or cytotoxicity [10-12]. Nevertheless, when nano-silver modified resin adhesives were used in bonding orthodontic brackets, the shear bond strength was decreased,[1,13] causing debonding and increased treatment time and cost $[2,14]$.

Hence, it was of prime importance to develop a clinically acceptable orthodontic adhesive having antimicrobial features, in addition to satisfactory mechanical properties. Espinosa et al showed that deproteinizing the enamel with sodium hypochlorite $(\mathrm{NaOCl})$ before etching increased the quality of the etching pattern (type 1 and 2), [15] because $\mathrm{NaOCl}$ eliminated the organic substance that prevented efficient etching causing type 3 etching pattern $[2,15]$. Deproteinizing agents vary according to their $\mathrm{pH}$ and their chemical action on proteins; $\mathrm{NaOCl}$ has a pH11 while polyethylene glycol 400 (PEG 400) pH6 and citric acid pH 3.2. PEG 400 is considered a protein salting out agent; on the other hand, citric acid disrupts the hydrogen bond in the proteins [16-18].
Based on this information it can be speculated that deproteinizing the enamel surface might enhance the bond strength of orthodontic brackets to the enamel. To our Knowledge, no study investigated the effect of enamel deproteinization on the adhesive strength of nano-silver modified adhesives using citric acid or PEG 400.

Accordingly, this study attempted to investigate the effect of enamel deproteinization using citric acid, PEG 400 and NaOCL on the shear bond strength of orthodontic brackets to enamel using nano-silver modified resin for the prevention of white spot lesions.

\section{MATERIAL AND METHODS}

\section{Material}

The materials used in this in-vitro study were listed in Table I. Characterization of the Silver-nano particles was done according to Riad et al. in 2015 [1]. The $\mathrm{pH}$ values of the deproteinizing agents were recorded using a digital pH meter (Orion, 710 A, USA); Table I.

Table I - Materials used in the study

\begin{tabular}{|c|c|c|}
\hline Material & Description & Manufacturer \\
\hline $0.56 \mathrm{~mm}$ Roth brackets & 0.22 slot & $\begin{array}{l}\text { Rx, 3M Gemini metal } \\
\text { brackets }\end{array}$ \\
\hline $\begin{array}{l}\text { Non fluoride Rely-a- } \\
\text {-bond }\end{array}$ & $\begin{array}{l}\text { No mix adhesive resin. } \\
\text { Primer and adhesive paste. }\end{array}$ & $\begin{array}{l}\text { Reliance Orthodontic } \\
\text { Products, Itasca, III }\end{array}$ \\
\hline Rely-a-bond & Etching gel & $\begin{array}{l}\text { Reliance Orthodontic } \\
\text { Products, Itasca, III }\end{array}$ \\
\hline Silver Nano-particles & $\begin{array}{l}\text { Molecular weight: } 107.87 \mathrm{~g} / \\
\text { mol. } \\
\text { Form: powder }\end{array}$ & $\begin{array}{l}\text { Sigma Aldrich, St. Louis, } \\
\text { M0 }\end{array}$ \\
\hline Sodium hypochlorite & $\begin{array}{c}\text { pH: } 11 \\
5.25 \% \\
\text { Liquid } \\
\text { Damage the amino acids back } \\
\text { bone and/or side chains }{ }^{[16]} \\
\text { Chemical formula: } \mathrm{NaOCl}\end{array}$ & $\begin{array}{c}\text { Clorox } \mathrm{Co}_{0 .}, 1^{\text {th }} \text { of Rama- } \\
\text { dan, Egypt. }\end{array}$ \\
\hline $\begin{array}{l}\text { Polyethylene glycol } \\
400 \text { (PEG 400) }\end{array}$ & $\begin{array}{c}\mathrm{pH}: 6 \\
5 \% \\
\text { Liquid } \\
\text { Protein salting out agent }{ }^{[17,18]} \\
\text { Chemical formula: } \\
\mathrm{HO}\left(\mathrm{C}_{2} \mathrm{H}_{4} \mathrm{O}\right) \mathrm{H}\end{array}$ & $\begin{array}{l}\text { Sigma Aldrich, St. Louis, } \\
\text { MO. }\end{array}$ \\
\hline Citric acid solution & $\begin{array}{c}\text { pH:3.2 } \\
10 \% \\
\text { Solution prepared by dis- } \\
\text { solving citric acid powder in } \\
\text { distilled water } \\
\text { Disrupt the hydrogen bond in } \\
\text { proteins }{ }^{[19]} \\
\text { Chemical formula: } \mathrm{C}_{6} \mathrm{H}_{8} \mathrm{O}_{7}\end{array}$ & $\begin{array}{l}\mathrm{Rx}, 3 \mathrm{M} \text { Gemini metal } \\
\text { brackets }\end{array}$ \\
\hline
\end{tabular}




\section{Methods}

Preparation of nano-silver modified adhesive resin primer

A $100 \mu \mathrm{g}$ nano-silver powder was weighed using a 4 digits sensitive balance (Sartorious AZ 214, Sartorious Mechatronics Corp, USA). The powder was shaken in an amalgamator for 3 minutes using an empty, clean amalgam capsule; to avoid particles' agglomeration. Then, $1 \mathrm{ml}$ of the adhesive resin primer was added to the powder using a micropipette; so that the final concentration of nano-silver (NS) in the adhesive resin primer was $100 \mu \mathrm{g} / \mathrm{ml}$. Dark glass bottles were used to store the prepared NS modified adhesive primer. The material was sonicated in an ultrasonic mixer (Eumax model: UD100SH3LQ, China) to insure proper mixing, and the procedure was performed in a dark environment using an X-ray processing box [20].

\section{Sample size calculation and grouping}

Sample size calculation was done at $90 \%$ power 95\% confidence interval. To compensate for non-parametric distribution; the sample size was increased by 15\%; thus, the final sample size was 20 specimens for surface roughness measurements and 40 for shear bond strength measurements and 8 for the scanning electron microscope examination.

Finally, a total of sixty-eight sound, freshly extracted premolars for orthodontic purpose were collected. Only teeth with no cracks, restorations, or developmental lesions were selected and stored in thymol solution $(0.025 \%)$ at room temperature. They were cleaned using water slurry of pumice with a rotary polishing brush. Scaling was done to remove any remaining calculus.

A computer-generated randomization list (random.org) was then used to equally and randomly distribute the teeth into four groups. The teeth were put in numbered, opaque and sealed envelopes; each containing 17 extracted teeth.
Group I (control): Enamel was acid etched with 37\% phosphoric acid for 30s, rinsed with distilled water for 20s and air dried.

Group II: Enamel was deproteinized using $5.25 \%$ sodium hypochlorite $(\mathrm{NaOCl})$ applied with a small brush and left for 20s.

Group III: Enamel was deproteinizated using 10\% citric acid applied with a small brush and left for 20s.

Group IV: Enamel was subjected to deproteinization using 5\% polyethylene glycol (PEG 400) applied with a small brush for 20s.

In groups II,III and IV the deproteinization was followed by rinsing with distilled water for another 20s,[15,21] then acid etching as in group I.

\section{I- Surface roughness test}

Five specimens from each group ( $\mathrm{n}=$ 5) were used and embedded horizontally in modeling wax, with their proximal surfaces exposed. Ra measurements were performed using a TR 220 surface roughness profilometer (Time Group Inc. China) with a diamond stylus (tip radius of $5 \mu \mathrm{m}$ ) passing across $0.8 \mathrm{~mm}$ length in a cut off value of $0.25 \mathrm{~mm}$. Three measurements were performed in different directions for each surface, the average of which was considered the Ra value for the tested specimen.

\section{II- Shear bond strength measurement}

Ten specimens from each group $(\mathrm{n}=10)$ were embedded vertically in self-cured acrylic resin blocks, with the cemento-enamel junction at the resin surface. After deproteinization and etching, the adhesive primer was applied to the tooth surface and the bracket base. The adhesive resin paste was then applied to the brackets $(\mathrm{Rx}$, 3M Gemini 0.022" slot, metal brackets),[1] which were seated in place using hand pressure, then a load of $300 \mathrm{gm}$ was applied for 30 s to standardize the pressure on brackets [22]. LED light (Valo, Ultradent Products, Utah, USA) at $1000 \mathrm{~mW} /$ $\mathrm{cm}^{2}$ was used for curing the adhesive,10s from each side of the bracket (a total of 40s for each specimen) [1]. 


\section{Thermocycling}

The specimens were stored in distilled water at room temperature for 24 hours, they were thermo-cycled (Thermoscientific 1100, Mechatronic $\mathrm{GmbH}$ ) between $5^{\circ} \mathrm{C}$ and $55^{\circ} \mathrm{C}$ for 6000 cycles; for a dwell time of 30s in each bath and transfer time of 10s between baths [23].

\section{Shear bond strength test:}

A 020" stainless steel wire was looped around the lower wings of each premolar bracket. The wire loop was attached to the cross head of the machine. A gingivo-occlusal force with a crosshead speed of $0.5 \mathrm{~mm} / \mathrm{min}$ was exerted onto each specimen (Instron Instruments 3365, USA), producing a shear force at the brackettooth interface, until the bracket was detached. The shear bond strength (SBS) value for each specimen was determined in mega Pascals ( $\mathrm{MPa})$ $[2,22]$.

\section{III- Failure mode assessment}

After the brackets were debonded, the enamel surface was examined for the sites and modes of bond failure, and the amount of residual adhesive on each tooth. The modified Adhesive Remnant Index (ARI) [2, 24] was determined according to the following scale:

Score 1 = all of the bonding resin, with an impression of the bracket base seen on it, remained on the tooth surface; Score $2=$ more than 90 per cent of the bonding resin remained on the tooth surface; Score $3=$ more than 10 per cent but less than 90 per cent of the bonding resin remained on the tooth; Score $4=$ less than 10 per cent of the bonding resin remained on the tooth; and Score $5=$ no bonding resin remained on the tooth.

\section{examination}

\section{IV- Scanning electron microscopic}

It was used to assess the topography of the enamel surface after deproteinization. Two specimens were taken from each group to examine the combined effect of deproteinization followed by acid etching. For the control group, the specimens were examined to show the acid etching effect alone. They were mounted on aluminum tubs and gold sputtering was performed using a gold sputter coater (SPI Module, USA). Enamel surfaces were then observed under scanning electron microscope (JSM $5500 \mathrm{LV}$, JEOL Ltd, Japan) at a magnification of $1800 \mathrm{X}$.

\section{Statistical Analysis}

Statistical analysis was performed with IBM $®$ SPSS $₫$ Statistics Version 20 for Windows. Mean and standard deviation values were calculated for each group in each test. Data were explored for normality using KolmogorovSmirnov and Shapiro-Wilk tests. Data for shear bond strength and surface roughness showed parametric (normal) distribution. However, failure mode showed non-parametric (notnormal) distribution. For parametric data; Oneway ANOVA followed by Tukey post hoc test was used to compare between more than two groups in non-related samples. For non-parametric data; Kruskal Wallis test was used to compare between more than two groups in non-related samples. Mann Whitney test was used to compare between two groups in non-related samples.

The significance level was set at $\mathrm{p} \leq 0.05$

\section{RESULTS}

\section{Results of nano- silver characterization}

They were characterized regarding their optical properties using UV absorption spectra. The spectrum exhibited Plasmon bond at $\approx 434$ $\mathrm{nm}$, which indicated the formation of spherical silver nano- particles.

Transmission electron micrographs revealed the spherical shape of the particles and their size $(65-100 \mathrm{~nm})$.

\section{I- Surface roughness results:}

A statistically significant difference was observed between Groups I, II, III and IV ( $\mathrm{p}<$ 0.001).

A statistically significant difference was found between Group I and either Group II or Group III ( $\mathrm{p}<0.001)$. On the other hand, no 
statistically significant difference was found between Group I and Group IV ( $p=0.998)$.

A statistically significant difference was found between Group II and either Groups III or IV ( $\mathrm{p}<0.001)$. Also, a statistically significant difference was found between Groups III and IV ( $\mathrm{p}<0.001)$.

that Group III (citric acid) showed the highest surface roughness values, followed by Group II (sodium hypochlorite). However, the least surface roughness values were given out by Groups I (control) and IV (PEG 400); Table II.

Table II - Means and standard deviations (SD) of Ra surface roughness values $(\mu \mathrm{m})$ in different groups

\begin{tabular}{|ccc|}
\hline Groups & Mean & SD \\
\hline Group I & $0.13^{\mathrm{c}}$ & 0.03 \\
\hline Group II & $0.52^{\mathrm{b}}$ & 0.03 \\
\hline Group III & $1.00^{\mathrm{a}}$ & 0.05 \\
\hline Group IV & $0.13^{\mathrm{c}}$ & 0.03 \\
\hline p-value & & $<0.001^{\star}$ \\
\hline
\end{tabular}

*significant $(p<0.05) \quad n s ;$ non-significant $(p>0.05)$

Same superscript letters denote no statistically significant difference between groups, while different superscript letters denote presence of significant difference.

\section{II- Shear bond strength results:}

A statistically significant difference was observed between Groups I, II, III and IV ( $\mathrm{p}<$ 0.001).

A statistically significant difference was found between Group I and either Groups II or III ( $\mathrm{p}<0.001$ ). On the other hand, no statistically significant difference was found between Groups I and IV ( $\mathrm{p}=0.948)$.

A statistically significant difference was found between Group II and either Groups III or IV ( $\mathrm{p}<0.001)$. Also, a statistically significant difference was found between Groups III and IV ( $p<0.001$ ). Group III (citric acid) showed the highest SBS values, followed by Group II (sodium hypochlorite). However, the least SBS values were observed in Groups I (control) and IV (PEG 400); Table III.
Table III - Means and standard deviations (SD) of shear bond strength values (MPa) among different groups

\begin{tabular}{|c|c|c|}
\hline Groups & Mean & SD \\
\hline Group I & $6.34^{c}$ & 1.09 \\
\hline Group II & $12.05^{b}$ & 1.12 \\
\hline Group III & $18.13^{a}$ & 1.40 \\
\hline Group IV & $6.62^{\mathrm{c}}$ & 0.86 \\
\hline$p$-value & \multicolumn{2}{|c|}{$<0.001^{\star}$ significant } \\
\hline
\end{tabular}

*significant $(p<0.05) \quad n s ;$ non-significant $(p>0.05)$

Same superscript letters denote no statistically significant difference between groups, while different superscript letters denote presence of significant difference.

\section{III- Results of failure mode assessment:}

\section{A: Failure mode scores:}

Failure mode scores among different groups were demonstrated in the form of their frequency of distribution (\%). There was a statistically significant difference between all groups; $\mathrm{p}<0.001$.

Group I showed 0 specimens (0\%) with score 1,0 specimens (0\%) with score 2, 0 specimens (0\%) with score 3 , 4 specimens (40\%) with score 4 and 6 specimens (60\%) with score 5 .

Group II; showed1 specimen (10\%) with score 1, 4 specimens (40\%) with score 2, 5 specimens (50\%) with score 3 , 0 specimens $(0 \%)$ with score 4 and 0 specimens (0\%) with score 5.

Group III showed 4 specimens (40\%) with score 1, 5 specimens (50\%) with score 2,1 specimen (10\%) with score 3 , 0 specimens $(0 \%)$ with score 4 and 0 specimens (0\%) with score 5 .

While Group IV showed 0 specimens (0\%) with score 1,0 specimens (0\%) with score 2,1 specimen (10\%) with score 3, 4 specimens (40\%) with score 4 and 5 specimens (50\%) with score 5 .

\section{III-B: Characterization of failure mode}

The type of failure was delineated under stereomicroscope; and shown in Figure 1. 

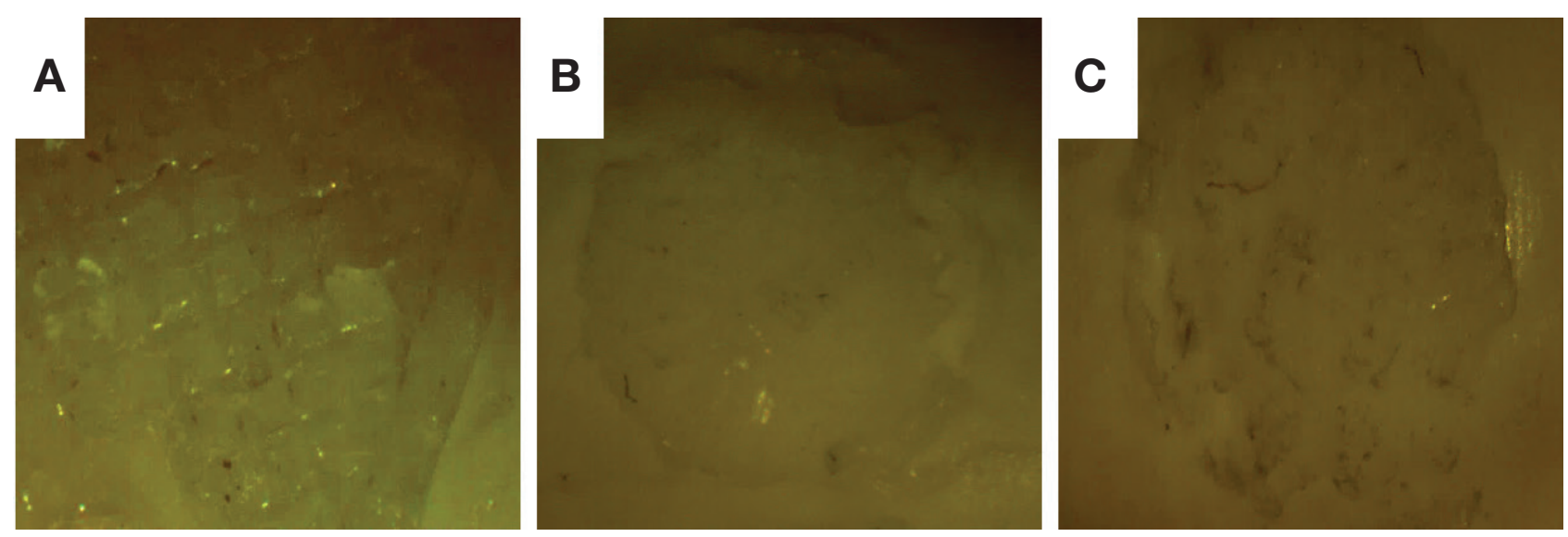

Figure 1 - Stereomicroscopic photos representing various types of failure: a: score 1, b: score 5, c: score 2,3,4.

\section{IV- Scanning electron microscope results}

Deproteinization with either $\mathrm{NaOCl}$ or citric acid before acid etching resulted in a rougher surface (etching pattern type 1), where dissolution of the core of enamel prisms occurred leaving the interprismatic material intact; honey comb appearance (Figure 2a and $2 \mathrm{~b}$ white arrows). Also, type 2 etching pattern was observed in some areas; showing dissolution of enamel rods' peripheries, with intact enamel rod core material; cobblestone like appearance (Figure $2 \mathrm{a}$ and $2 \mathrm{~b}$ yellow arrows). The interprismatic grooves created in type 2 etching pattern were deeper and more profound in the citric acid group giving a surface topography of higher roughness and more retentive features.

The PEG 400 and the control groups displayed type 3 etching pattern in some areas showing surface irregularities with no specific features or changes in the enamel prisms (Figure $2 \mathrm{c}$ and $2 \mathrm{~d}$ red arrows). Also, type 4 etching pattern was observed displaying a random distribution of depressions with no preferential destruction of prism cores or peripheries and some areas were left poorly etched (Figure $2 \mathrm{c}$ and $2 \mathrm{~d}$ blue arrows).
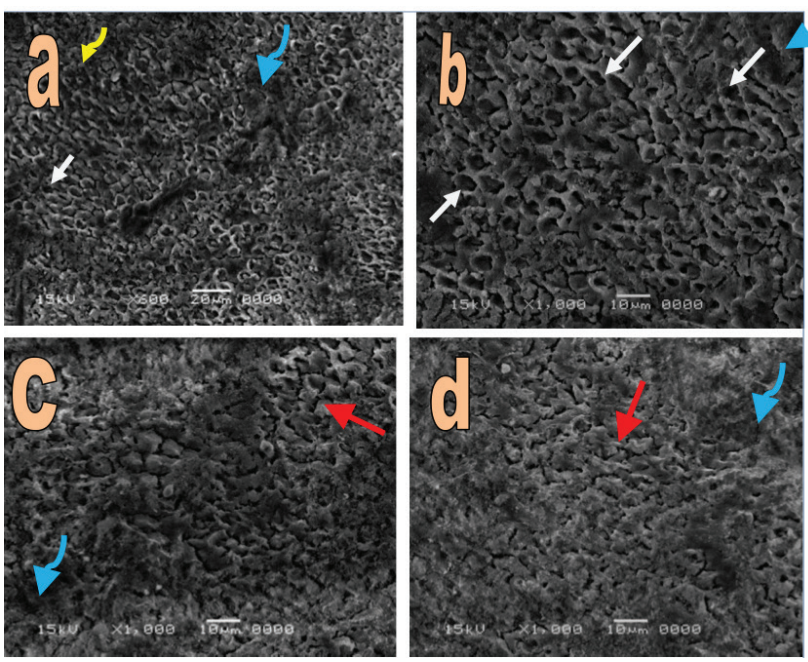

Figure 2 - a: SEM, deproteinization with $\mathrm{NaOCl}$ showing types 1 and 2 etching patterns. b: SEM, deproteinization with citric acid showing types 1 and 2 etching patterns. c: SEM, deproteinization with PEG 400 showing types 3 and 4 etching patterns. d: SEM of acid etched enamel surface, showing types 3 and 4 etching patterns.

\section{DISCUSSION}

Orthodontic patients suffer from a relatively high incidence of white spot lesions as fixed orthodontic appliances present a difficulty for satisfactory oral hygiene maintenance. In addition, patients may not make regular dental visits for plaque control which results in subsequent enamel decalcification $[1,2]$. 
On the other hand, the antimicrobial effects of the nano-silver modified orthodontic adhesives were not utilized due to the reduced bond strength and bond failure they provide [1] Enamel deproteinization, using $\mathrm{NaOCl}$, to improve adhesive bond strength was discussed in the literature, $[2,15,21,25]$ and its application offered an opportunity for taking both benefits. Further, the use of citric acid and PEG 400 was attempted as a first in the literature.

The wire loop method was chosen for SBS testing because it simulated clinical loads and offered better stress distribution at the bracket/ enamel interface compared to the knife edge chisel method[22,26-28] Furthermore, thermocycling was considered to be pivotal in simulating the clinical duration of orthodontic treatment and in inducing a thermal aging effect unlike other research which investigated short term bond strength [29].

The results showed that deproteinization using either $\mathrm{NaOCl}$ (group II) or citric acid (group III) resulted in significantly higher a SBS compared to PEG 400 (group IV) and group I (control; acid etching only). On the other hand, PEG 400 resulted in SBS values comparable to the control group. This could be attributed to their different mechanisms of protein denaturation, and their diverse $\mathrm{pH}$ values. $\mathrm{NaOCl}$ is an agent of high redox potential, inducing widespread destabilization of the protein tertiary structure. Its alkaline $\mathrm{pH}$ allows hydrogen atom abstraction at the $\alpha$ - carbon; resulting in fragmentation of the protein backbone and a stronger adhesive junction [21,30-31]. Justus et al. [2] reported comparable results; nevertheless the increase was more on using resin modified glass ionomer rather than composite. This difference could be attributed to the fact that the composite used in this study was modified by the addition of the silver nanoparticles which increased the bond strength. Likewise, Sharma et al. reported an increase in SBS using $\mathrm{NaOCl}$ on teeth with flurosis [25]. Regarding the citric acid, its free hydrogen ions interacted with proteins altering their molecular structure and breaking the hydrogen bonds that held the protein chains in a twisted manner; which caused proteins to disentangle and denature. Besides, its acidic pH could be considered as an augmentation to the acid etching procedure causing deeper enamel micro-porosities allowing greater penetration of the adhesive. The SBS, hence was increased compared to acid etching per se or deproteinization using $\mathrm{NaOCl}$ [32].

With respect to PEG 400 (group IV), no statistically significant difference was observed compared to the control group (group I). This concluded that the salting out of proteins produced by PEG was not effective for enamel deproteinization.

It is logically expected that as the surface roughness of enamel increased, the infiltration and mechanical interlocking of the adhesive resin within the enamel micro-pores increased; hence the strength of the adhesive junction increased as well. The surface roughness results showed that citric acid (group III) induced deeper microporosities resulting higher roughness, while PEG 400 (group IV) showed the lowest surface roughness that was comparable to acid etching per se (group I).

Aiming to attain a more comprehensive explanation for the obtained results; SEM investigation of the deproteinized enamel was performed and the results concurred with the SBS and the surface roughness test results.

Accordingly, the observed failure mode in the groups deproteinized using $\mathrm{NaOCl}$ and citric acid was mainly a cohesive failure unlike that seen in another study where their sample showed an adhesive failure at the bracket/resin interface [2]. This might have resulted from the difference in nature and composition of the used bonding resin. On the other hand, the failure in the PEG 400 and acid etch per se groups occurred at the bonding resin/ tooth interface; which indicated the possibility of more often bracket failure during treatment[2]. 


\section{CONCLUSIONS}

1- Deproteinization of enamel using either $\mathrm{NaOCl}$ or citric acid increased the bond strength of nano-silver modified resin to enamel, with citric acid showing a greater increase in bond strength.

2- Deproteinization using PEG 400 did not increase the bond strength.

\section{Acknowledgments}

Not applicable.

\section{Funding}

This research did not receive any specific grant from funding agencies in the public, commercial, or not-for-profit sectors.

\section{Conflict of interest}

The authors declare no conflict of interest.

\section{Regulatory Statement}

This study was conducted in accordance with all the provisions of the local human subject's oversight committee guidelines and policies of the Medical Research Ethics Committee, National Research Centre. The approval code for this study is: $20 / 014$.

\section{REFERENCES}

1. Riad M, Harhash AY, Elhiny OA, Salem GA. Evaluation of the shear bond strength of orthodontic adhesive system containing antimicrobial silver nano- particles on bonding of metal brackets to enamel. Life Sci J. 2015;12(12):27-34.

2. Justus R, Cubero T, Ondarza R, Morales F: A new technique with sodium hypochlorite to increase bracket shear bond strength of fluoride-releasing resin modified glass ionomer cements: comparing shear bond strength of two adhesive systems with enamel surface deproteinization before etching. Semin Orthod 2010;16:66-75.

3. Miresmaeili A, Atai M, Mansouri K, Farhadian N. Effect of nano-silver incorporation on antibacterial properties and bracket bond strength of composite resin. Iran J Orthod. 2012;7:14-19.

4. Arhun N, Arman A, Cehreli SB, Arikan S, Karabulut E, Gül ahi K. Microleakage beneath ceramic and metal brackets bonded with a conventional and an antibacterial adhesive system. Angle Orthod. 2006 Nov;76(6):1028-34. doi: 10.2319/101805-368.

5. Lim BS, Lee SJ, Lee JW, Ahn SJ. Quantitative analysis of adhesion of cariogenic streptococci to orthodontic raw materials. Am J Orthod Dentofacial Orthop. 2008 Jun;133(6):882-8. doi: 10.1016/j.ajodo.2006.07.027.
6. Khoroushi M, Kachuie M. Prevention and treatment of white spot lesions in orthodontic patients. Contemp Clin Dent. 2017 Jan-Mar;8(1):11-19. doi: 10.4103/ccd.ccd 21617.

7. Benham AW, Campbell PM, Buschang PH. Effectiveness of pit and fissure sealants in reducing white spot lesions during orthodontic treatment. A pilot study. Angle Orthod. 2009 Mar;9(2):338-45. doi: 10.2319/022808-30.1.

8. Leizer C, Weinstein M, Borislow AJ, Braitman LE. Efficacy of a filled-resin sealant in preventing decalcification during orthodontic treatment. $\mathrm{Am}$ J Orthod Dentofacial Orthop. 2010 Jun;137(6):796-800. doi: 10.1016/j. ajod0.2008.11.025

9. Hammad SM, Knösel M. Efficacy of a new sealant to prevent white spot lesions during fixed orthodontic treatment: A 12-month, single-center, randomized controlled clinical trial. J Orofac Orthop. 2016 Nov;77(6):439-45. English. doi: 10.1007/s00056-016-0052-2.

10. Antibacterial properties of composite resins incorporating silver and zinc oxide nanoparticles on Streptococcus mutans and Lactobacillus. Restor DentEndod. 2014 May;39(2):109-14. doi: 10.5395/rde.2014.39.2.109.

11. Martínez-Robles AM, Loyola-Rodríguez JP, Zavala-Alonso NV, MartinezMartinez RE, RuizF, Lara-Castro RH, et al. Antimicrobial properties of biofunctionalized silver nanoparticles on clinical isolates of streptococcus mutans and its serotypes. Nanomater 2016;6(7):136-50.

12. Espinosa-Cristóbal LF, López-Ruiz N, Cabada-Tarín D, Reyes-LópezSY, Zaragoza-Contreras A, Constandse-Cortéz D, et al. Antiadherence and antimicrobial properties of silver nanoparticles against streptococcus mutans on brackets and wires used for orthodontic treatments. J Nanomater 2018;2018:1-11.

13. Elkassas DW, Haridy MF Degree of conversion, flexural strength and bond strength durability of a contemporary universal dentin adhesive fortified with silver and hydroxy apetite nanoparticles. EDJ 2015;61(3):1-12.

14. Yuasa T, lijima M, Ito S, Muguruma T, Saito T, Mizoguchi. Effects of long-term storage and thermocycling on bond strength of two self-etching primer adhesive systems. Europ J Orthodont 2010;32:285-90.

15. Espinosa R, Valencia R, Uribe M, Cejal, Saadia M. Enamel deproteinization and its effect on acid etching. An in vitro study. J Clin Pediatr Dent 2008;33(1):13-20.

16. Hawkins CL, Davies MJ. Hypochlorite-induced damage to proteins: formation of nitrogen-centred radicals from lysine residues and their role in protein fragmentation. Biochem J. 1998;15:617-25.

17. Vineet K, Vikas K, Sharma, Devendra S, Kalonia. Effect of polyols on polyethylene glycol (PEG)-induced precipitation of proteins: Impact on solubility, stability and conformation. Int J Pharma. 2009;366:38-43.

18. Vinod BD, Conan JF, Ketul CP. Formation of protein complex with the aid of polyethylene glycol for deproteinized natural rubber latex. Appl Surf Sci. 2010;256:4894-901.

19. Aktaş N, Kaya M. Influence of weak organic acids and salts on the denaturation characteristics of intramuscular connective tissue. A differential scanning calorimetry study. Meat Sci. 2001 Aug;58(4):413-9. doi: 10.1016/s0309-1740(01)00044-4.

20. Mohammed HF, Riad MI. The effect of silver nano- particles incorporation in the self-etch adhesive system on its antibacterial activity and degree of conversion: an in-vitro study. F1000 Res. 2019;8:244-52.

21. Panchal S, Ansari A, Jain AK, Garg Y.Effects of different deproteinizing agents on topographic features of enamel and shear bond strength - An in vitro study. J Orthod Sci. 2019 Oct 4;8:17. doi:10.4103/jos.JOS 2619. 
22. Chalipa J, Akhondi MS, Arab S, Kharrazifard MJ, Ahmadyar M. Evaluation of shear bond strength of orthodontic brackets bonded with nano-filled composites. J Dent (Tehran). 2013 Sep;10(5):461-5. Epub 2013 Sep 30. PMID: 24910655; PMCID: PMC4025415.

23. Yuasa T, lijima M, Ito S, Muguruma T, Saito T, Mizoguchi I. Effects of long-term storage and thermocycling on bond strength of two self-etching primer adhesive systems. Eur J Orthod. 2010 Jun;32(3):285-90. doi: 10.1093/ejo/ cjp118.

24. Bishara SE, Ostby AW, Laffoon JF, Warren J. Shear bond strength comparison of two adhesive systems following thermocycling. A new self-etch primer and a resin-modified glass ionomer. Angle Orthod. 2007 Mar;77(2):337-41. doi:10.2319/0003-3219(2007)077[0337:SBSCOT]2.0.C0;2.

25. Sharma R, Kumar D, Verma M. Deproteinization of fluorosed enamel with sodium hypochlorite enhances the shear bond strength of orthodontic brackets: an in vitro study. Contemp Clin Dent. 2017 Jan-Mar;8(1):20-5. doi: 10.4103/ccd.ccd_934_16.

26. Mojtahedzadeh F, Akhoundi MS, Noroozi H. Comparison of wire loop and shear blade as the 2 most common methods for testing orthodontic shear bond strength. Am J Orthod Dentofacial Orthop. 2006 Sep;130(3):385-7. doi: 10.1016/j.ajodo.2006.03.021.
27. Akhoundi MS A, Mojtahedzadeh F: Problems in standardization of orthodontic shear bond strength tests; A Brief Review. J Dent Tehran Univ Med Sci. 20052(1):36-40.

28. Elshal MG, Refai WM. The effect of incorporating gold and silver nano particles in orthodontic adhesive system on bond strength of orthodontic bracket. EC Dent Sci 2017; 11(4):119-31.

29. Yuasa T.Effects of long-term storage and thermocycling on bond strength of two self-etching primer adhesive systems. Eur J Orthod 2010;32:285-90.

30. Finnegan M, Linley E, Denyer SP, McDonnell G, Simons C, Maillard J. Mode of action of hydrogen peroxide and other oxidizing agents: differences between liquid and gas forms. J Antimicrob Chemother 2010;65:2108-15.

31. Silveira AC, Conesa A, Aguayo E. Alternative sanitizers to chlorine for use on fresh-cut 'Galia' (Cucumis melovar.catalupensis) melon. J Food Sci. 2008;73:405-11.

32. Rao SA, Muralidhar T, Golla K. Evaluation of nanoleakage following deproteinization of dentin - a confocal laser scanning microscopic study. J Conserv Endodont 2017;2(2):61-5.

\section{Omnia A. Elhiny}

\section{(Corresponding address)}

Department of Orthodontics and Pediatric Dentistry, National Research Centre, Egypt. 